\title{
Door de Moleculen het Systeem niet meer zien
}

Citation for published version (APA):

Honing, M. (2018). Door de Moleculen het Systeem niet meer zien: Elektronen, Structuren en Activiteit. Maastricht University. https://doi.org/10.26481/spe.20180927mh

Document status and date:

Published: 27/09/2018

DOI:

10.26481/spe.20180927mh

Document Version:

Publisher's PDF, also known as Version of record

\section{Please check the document version of this publication:}

- A submitted manuscript is the version of the article upon submission and before peer-review. There can be important differences between the submitted version and the official published version of record.

People interested in the research are advised to contact the author for the final version of the publication, or visit the DOI to the publisher's website.

- The final author version and the galley proof are versions of the publication after peer review.

- The final published version features the final layout of the paper including the volume, issue and page numbers.

Link to publication

\footnotetext{
General rights rights.

- You may freely distribute the URL identifying the publication in the public portal. please follow below link for the End User Agreement:

www.umlib.nl/taverne-license

Take down policy

If you believe that this document breaches copyright please contact us at:

repository@maastrichtuniversity.nl

providing details and we will investigate your claim.
}

Copyright and moral rights for the publications made accessible in the public portal are retained by the authors and/or other copyright owners and it is a condition of accessing publications that users recognise and abide by the legal requirements associated with these

- Users may download and print one copy of any publication from the public portal for the purpose of private study or research.

- You may not further distribute the material or use it for any profit-making activity or commercial gain

If the publication is distributed under the terms of Article $25 \mathrm{fa}$ of the Dutch Copyright Act, indicated by the "Taverne" license above, 
Prof. dr. Maarten Honing

Faculty of Health, Medicine and Life Sciences

Door de moleculen het systeem niet meer te zien : elektronen, structuren \& activiteit 


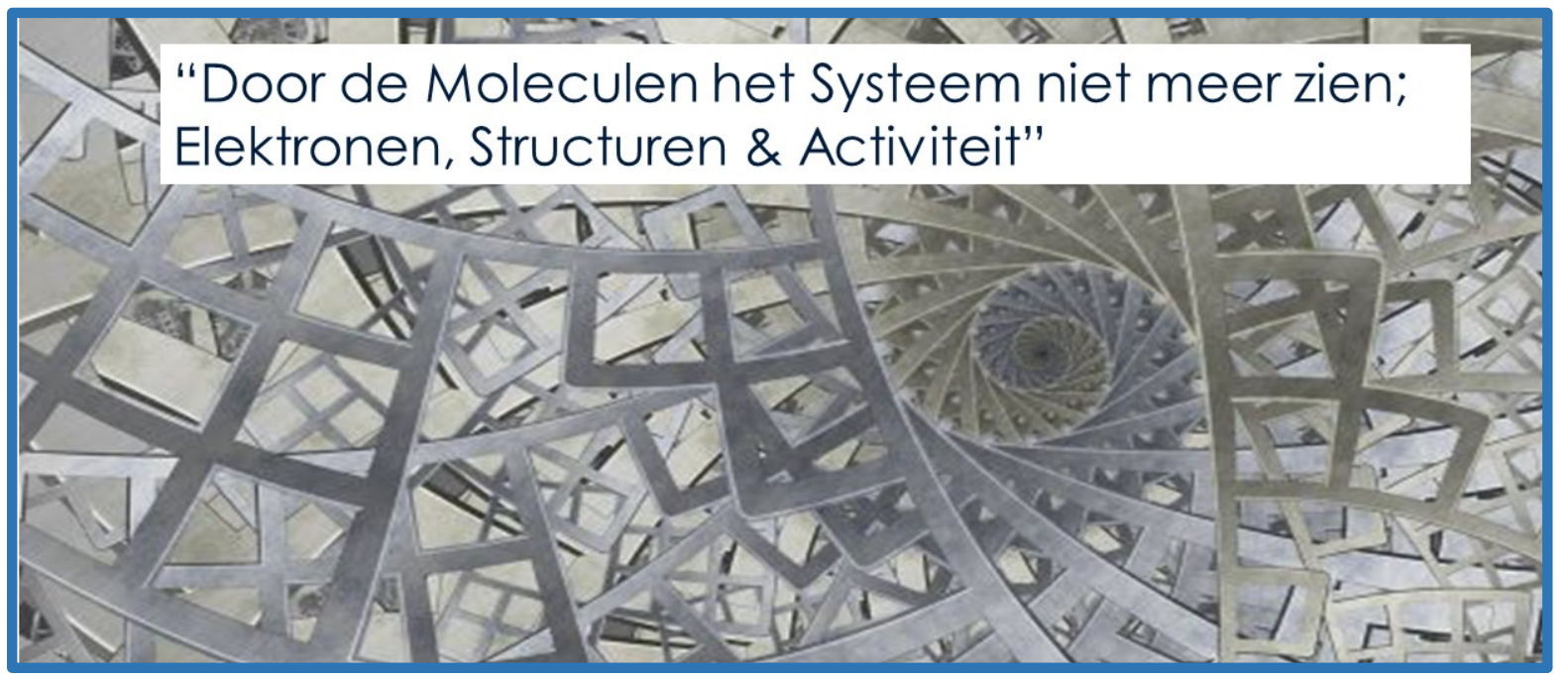

Dank u mevrouw de rector, voor deze introductie waarvan ik me afvraag of ik wel de persoon ben die aan die mooie woorden voldoet. Ik zal in deze rede in ieder geval trachten, de woorden ook gestand te doen. Ik sta hier met trots maar ook in zekere mate in nederigheid. Zeker als ik zo om mij heen kijk en zoveel kennis, inzichten en wetenschap zie zitten. Ik zie ook "Een interessant complex systeem opgebouwd uit veel individuen met "uni en bilaterale verbindingen". Interessant te zien of er tijdens de borrel eventueel nieuwe verbindingen of "uit evenwichten" situaties ontstaan".

Allereerst ben ik het College van Bestuur van de UM, het bestuur van de FHML en zeer zeker Albert Scherpbier en Nanne de Vries dank verschuldigd. In het bijzonder Albert voor het inspireren tot en verwezenlijken van mijn overstap naar de academie.

Ook dank aan Steven Olde Damink, de motor achter veel, en natuurlijk Ron en Peter die mij binnen M4l een thuis hebben gegeven. Ron voor de energie en de gezamenlijk wens een prachtig M4I instituut te bouwen. Thomas Cleij die mij de ruimte biedt om vanuit de medische faculteit de analytische chemie verder uit te breiden en de brug te slaan naar de Faculteit Science \& Engineering.

Dan natuurlijk Floris Rutjes en Bert Weckhuysen, om hun inspirerende woorden en het uitdagen van de analytische chemici tijdens het kleine symposium "Chemie in de Analyse en Analyse in de Chemie". Shane, Bart, Jules en Matt die het wetenschappelijk potentieel van deze universiteit voor het voetlicht hebben gebracht. Ik hoop in deze rede enkele antwoorden rondom de toekomst van de analytische chemie te geven. Dank voor jullie inspiratie. 


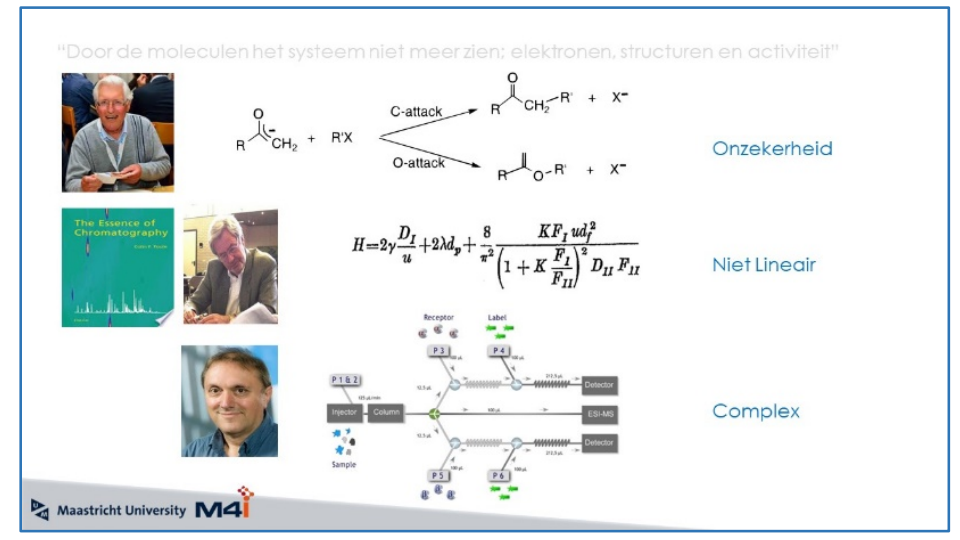

Voordat het openbare college inhoud krijgt wil ik stilstaan bij de personen die grote invloed hebben gehad op mijn wetenschappelijke vorming en levensloop.

- Nico Nibbering, die met zijn bevlogen college mij deed beslissen massa spectrometrie als een levensdoel te zien. Altijd motiverend, gaf hij steevast het antwoord op mijn vraag hoe de ambidente reactiviteit van enolate anionen in elkaar zat: "Honing elektronen tellen". Ik vond dat vreemd want ik had bij kwantummechanica toch geleerd dat als je wist waar ze waren dan wist je niet wat hun energie is. Zoiets als. Dus op het moment dat je denkt; "Ik weet wie ik ben" - "ben je er eigenlijk niet".

- Udo Brinkman, degene die sneller dan het licht kon presenteren. Het gebruik van meer dan 50 slides voor een presentatie van 20 minuten was niet ongewoon. In de analytische chemie wilde hij altijd alles aan elkaar koppelen wat ogenschijnlijk niet kon; hoewel hij in eerste instantie met het koppelen van LC met MS toch wel wat moeite had. Hij leerde mij "verwonderd te zijn van het "voor de hand liggende". Zoals, in het geval van een ijk lijn die lineair is over een groot concentratie bereik; juist dan moet je je als wetenschapper verbaasd zijn! De statistiek helpt ons die complexiteit achter "response curven" te verbergen. Mijn bewering is dan ook "Niets" in het leven is "lineair", en toch staan in veel proefschriften "lineaire correlaties" van complexe systemen. We hebben als wetenschappers kennelijk niet echt het vermogen om over complexe correlaties van complexe adaptieve uitevenwicht systemen te denken.

- Hubertus Irth, degene die bij mij na 15 jaar weer het academische onderzoek heeft ingetrokken. Vooral de tijd dat we gezamenlijk complexe analytische technieken bouwden om niet zozeer data te genereren maar om simultaan een beeld van moleculaire structuren en biologische activiteit te genereren. Ik hoop in de komende jaren onze samenwerking op het gebied van complexe technologische platformen voor te zetten. Ook om samen met Oscar van de Brink, de wetenschappelijke diepgang en toegevoegde waarde van de analytische chemie in Nederland te blijven uitdragen. 
In mijn tocht langs, Pharma-Bioresearch, Organon en DSM heb ik met wetenschappers uit de vele disciplines zoals organische en farmacologie, polymeer- \& proces chemie, mogen samenwerken. Ik wil enkelen memoreren:

- Carel Funke en Leon Orbons, die het pad voor mijn industriële R\&D-loopbaan gepolijst hebben. Leon, die wellicht onbedoeld mij vroeg om een groep van 7 analytici in midden Frankrijk te ondersteunen in het verkrijgen van de

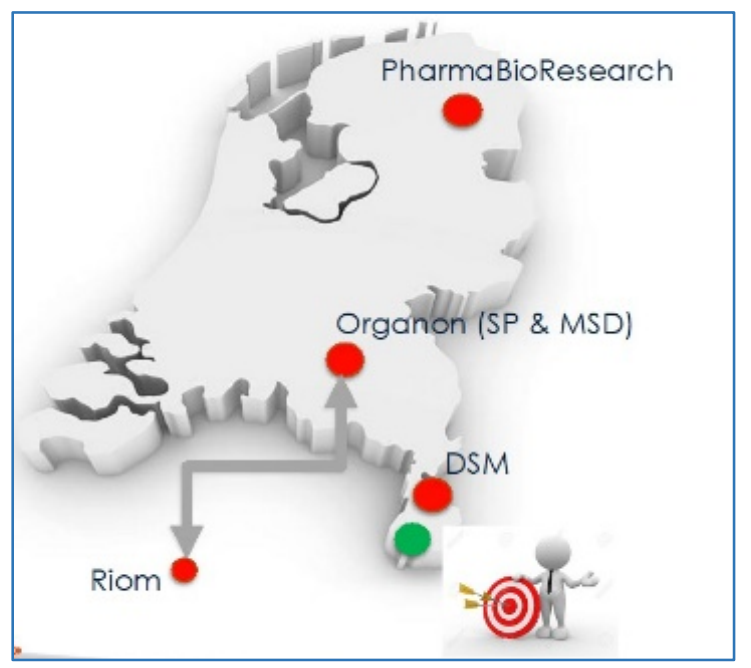
GLP status. Vanuit een 'people management' perspectief een echte achtbaan, waarin vertrouwen en inspireren de enige mogelijkheid was om een groep van R\&D-specialisten uit een passieve naar een proactieve toestand te krijgen.

- Stan van Boeckel die me de volle ruimte gegeven heeft om naar eigen inzicht een nieuwe analytische groep op te zetten. Mij ondersteunde om een "platte hoog entropische groep" te leiden. Maar vooral ook mij aanzette om na te denken over de vertaling van moleculaire structuren naar hun chemische en biologische activiteiten. We zijn het hier denk nog altijd over eens "we begrijpen er eigenlijk nog niets van"

- Bert Kip, die mij na het zinken van het schip in Oss, de gelegenheid gaf een nog grotere uitdaging aan te gaan. Het samen met mijn collega Michel Huys richting geven en inhoudelijke vormen van een "schijnbaar complexe analytisch chemische organisatie" die ultiem krachtig zou zijn in het stuwen van innovatie. Over uit evenwicht systemen gesproken. Berts onuitputtelijk vermogen om complexe organisatie te bouwen, en vooral ook te leiden was en is een inspiratie. Helaas is ook die reis plots afgebroken.

- En Paul Brandts, die mijn voor velen warrige en complexe wartaal over wetenschap en R\&D-organisaties in een kader kon en hopelijk nog veel gaat plaatsen. Paul "Complexity Sciences" krijgt nog steeds te weinig aandacht en hoop vandaag hiervoor een lans te breken. 


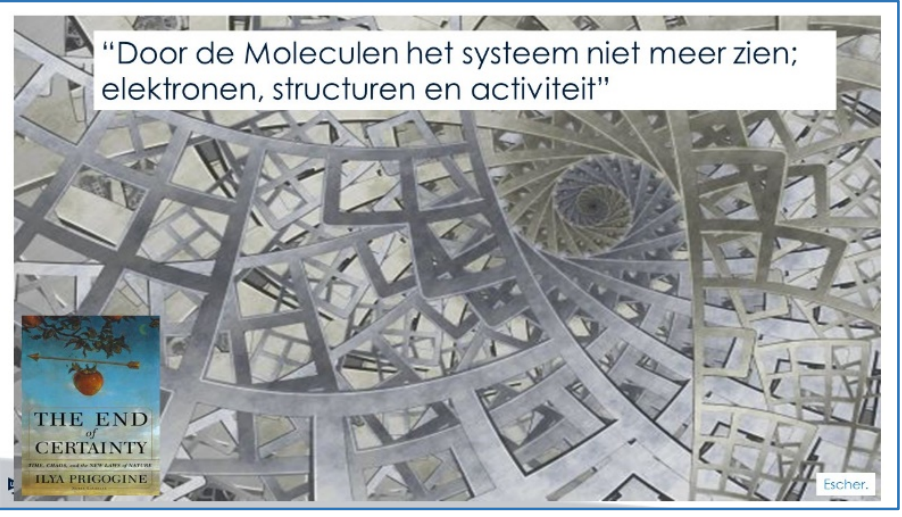

Beste CvB, Dekanen, Collega's vrienden en familie alvorens echt te beginnen, heeft $u$ wellicht al door dat de titel voor deze oratie gestoeld is op mijn wetenschappelijke vorming en "training on the Job" binnen verschillende R\&D-organisaties! Het gaat over het begrijpen van complexe systemen die uit evenwicht zijn en de daarbij horende onzekerheid, en de noodzaak studenten te vormen die de daarbij horende concepten begrijpen. Ik had een mogelijke positie als hoogleraar aan de UM nooit kunnen voorspellen, iets wat op zich niet verbaas en wekkend was! Vaak hoopte ik iemand te zijn maar wist ik niet waar, en als ik een positie had dan wist ik niet echt wat ik wilde zijn. Deze zogenaamde "Heisenberg onzekerheid" loopt door al onze carrières neem ik aan, en is het fundament van het leven vanuit de fundamenten van de fysica opgesloten.

De wel bekende uitdrukking "door de bomen het bos niet (meer) zien, heeft de betekenis als 'door te veel op details (de bomen) te letten, het geheel (het bos) uit het oog verliezen'. Ik begrijp dat ten zeerste en dat is mij meerdere keren tijdens mijn carrière gezegd; hou het simpel maak het niet complex. Het is inderdaad complex, maar ik heb het gevoel

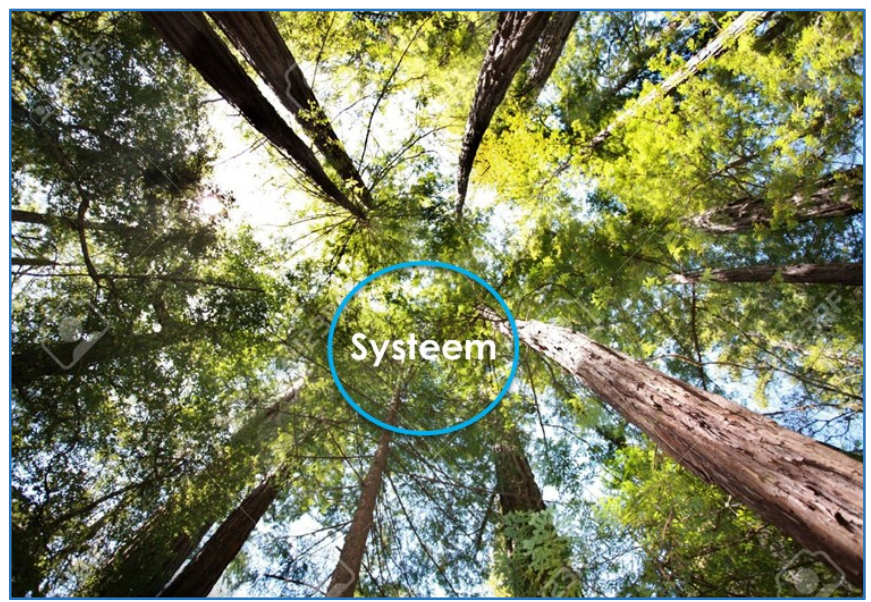
dat deze aanpak door een toenemend aantal managers en onderzoekers tot kunst wordt verheven. Big data sciences, A.I. en machine learning gaan ongetwijfeld een groot effect hebben op onze zoektocht naar de fundamenten, maar kan niet het enige doel zijn. Inzicht van en in zelfs de moleculaire processen in die bomen is de enige voorwaarde om de vertaling naar macroscopische processen te begrijpen. lets waar voor mij de grote Boltzman ook al tegenaan liep. Aan de andere kant, is het systeem bos weer onderdeel van een groter systeem zijnde een coherent geheel van elementen, die als één geheel functioneren. En zelfs als iets niet functioneert, functioneert het. Alleen, als dit bos na verloop van tijd bewoont gaat worden door anderen, dan wordt het bestaande evenwicht verstoord. We kunnen dat holistisch onderzoeken, 
echter mijns inziens is weldegelijk een fundamenteel inzicht in het evenwicht wat gestoeld is op de bomen, essentiële informatie voor wat er daarna gebeurd.

In analogie, als we op moleculair niveau kijken, dan kunnen de systemen in hun essentie alleen maar begrepen worden uit de fundamentele bouwstenen. Het begrip van moleculaire systemen, begint bij de activiteit van moleculen die weer nauw bepaald wordt door de elektronen die ergens zitten, of niet. Weet u nog die Heisenberg? Systemen in de breedste zin van het woord gaat over Materiaal, Maatschappij, groepen van mensen, organisaties, fabrieken en jawel cellen. Deze laatste bezien vanuit het moleculen: leidt bij diepgaand onderzoek tot verwondering (een woord dat ik gestolen heb van Cees Gooijer die het gebruikte bij zijn afscheidsrede aan de VU) en moet op een of andere manier iets te maken hebben met elektronen (wetenschap). Een Analytische chemicus moet kunnen redeneren vanuit het molecuul, zijn eigenschappen en de elektronen dichtheid en die vertalen naar activiteit om die vervolgens weer te meten. Het is geen "toegepast of technisch vak" waardoor het vaak als een toegepaste wetenschap gezien wordt. Essentieel is vanuit molecule te denken, en dat multimodaal een uitdagingen waaraan inhoud wil geven (de boog) in mij $n$ positie.

$U$ moet even wachten want alvorens ik ga vertellen hoe of wat ik wil gaan doen geef ik eerst nog gedurende 15 minuten een openbaar college over een domein wat ik nog niet ten zeerste begreep en graag zou willen door gronden.

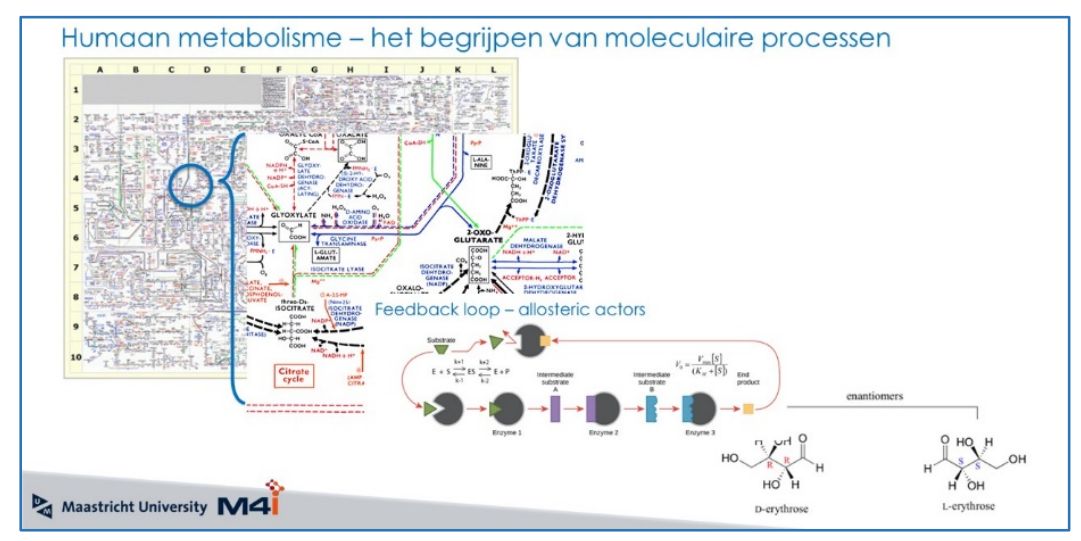

Allereerst in de zeventiger Jaren, tijdens mijn $\mathrm{HBO}$ opleiding klinische en immuno chemie, kwam ik in aanraking met de citroenzuur cyclus (Krebs cyclus) een complexe moleculair systeem, die ik om een goed cijfer te halen gewoon "van buiten leerde" zonder echt een beeld te krijgen van de moleculaire dynamiek en de complexiteit van de evenwicht reacties, de thermodynamica van het door enzymen en cofactoren gekatalyseerd systeem, waarbij "terugkoppeling" en stereochemie van moleculen een essentieel rol spelen. Ik zou zeggen een gemiste kans. 


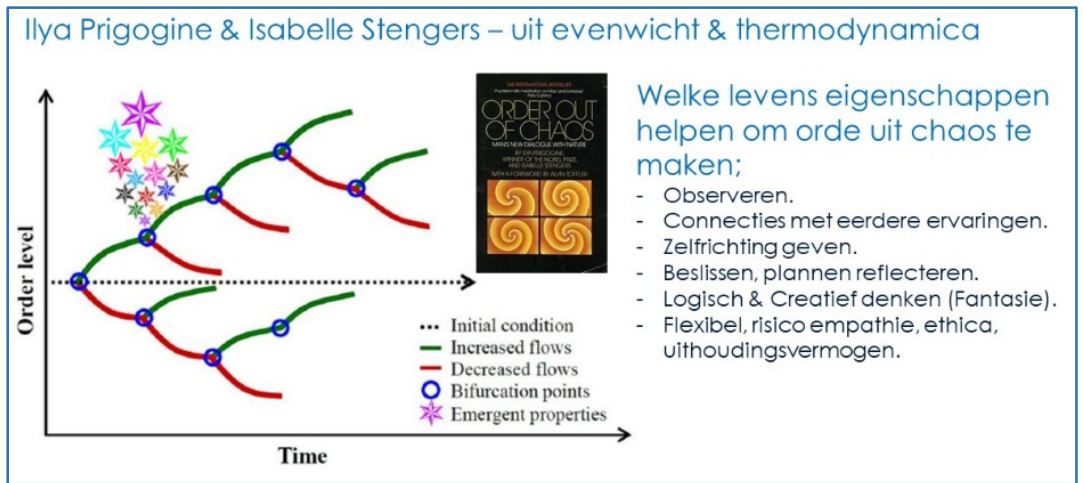

Ik kwam daar pas 7 jaar later achter tijdens mijn avondstudie chemie aan de Universiteit van Amsterdam, en wel bij de colleges kwantummechanica, fysische chemie, en de twee (misschien wel drie) herexamens. Daar leerde ik de fundamentele concepten van de thermodynamica, begrippen zoals chemische reactiekinetiek, moleculaire activiteit, evenals de Gibbs energie als basis van concentratie en stond verbaast dat er zogenaamde oscillerende reacties bestonden, die langzaam vanuit een niet evenwichtssituatie al oscillerend naar een soort van evenwicht bewoog. Vergelijk die met een slinger van een klok die heen en weer beweegt en afhankelijk van de weerstand oneindige "in evenwicht is". U kent hem wel, de slinger van foucault. Deze verwondering over de fundamentele processen werd aan gewakkerd door de fysisch chemicus en nobelprijs winnaar Ilya Prigogine die samen met de Vlaamse sociologe Isabelle Stengers in het boek "Orde uit Chaos" de thermodynamica van uit evenwichtssituaties in de chemie en samenleving beschreven. Hij is hiermee 1 van de grondleggers in de complexiteiten wetenschappen. Een boek en domein die ik in de komende jaren echt zou willen doorgronden.

Weer 7 jaar later, en tijdens mijn promotieonderzoek in Barcelona ontmoete ik een mooie biologe die mij vertelde over haar held - Ramon Margalef die in Barcelona, evenals Margalef (1958)- definitie van de "soorten rijkdom" in vit evenwicht Nico Nibbering in Amsterdam, op een

$$
d=\frac{(S-1)}{\operatorname{Ln} N}
$$

$S=$ totaal aantal soorten

$N=$ aantal individuen binnen een soort

Ln = de natuurlijk logaritme

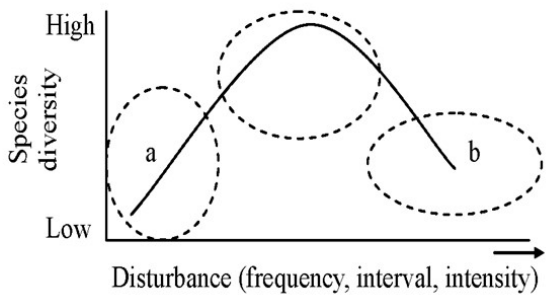

R. Margalef - "Natural Communities (1962), perspectives in Ecological Theory (1968) \& Ecology (1974)

zeer inspirerende manier over zijn vakgebied de ecologie doceerde. Hij beschreef in meerdere boeken het gebruik van wiskundige modellen om de veranderingen in een ecologisch evenwicht door toedoen van de verandering van het aantal en soorten zoogdieren en hun voedingsketen. Evenals Prigogine, die een leeftijd genoot was, geloofde hij sterk in adaptieve uit evenwicht en complexe systemen. Essentieel in deze filosofie is het begrip van biologische processen op het niveau van een individuele plant of dier, en die in de context 
van het complexe systeem te plaatsen. Je zou kunnen stellen dat al reeds in de 60 er jaren van de vorige eeuw de basis van de "Systeem Biology" gelegd werden, zonder dat we er nu rekenschap aan geven. Het zou prachtig zijn om met moderne 'Artificial Intelligence' en 'Machine Learning' een beter begrip te krijgen; maar zoals eerder gesteld zou ik echter willen pleiten om vanuit het gedachte-experiment en de creativiteit van de brein, de fundamenten te blijven begrijpen en onderwijzen.

In diezelfde periode, werd de wellicht latent interesse in de geschiedenis geactiveerd door een beter begrip van de Spaanse historie. Met de uitleg dat "Languedoc" het frans was voor "de taal van de De Europese geschiedenis - onze samenleving is al meer dan 2000 jaar uit evenwicht en nog steeds....

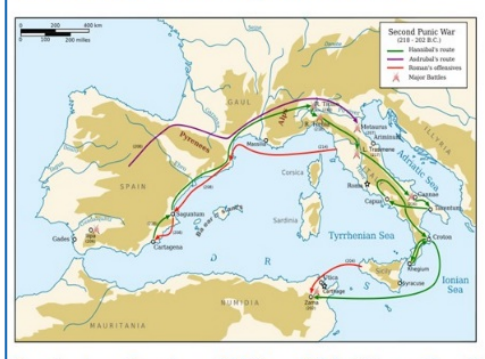

Punische Oorlog (200 v Ch) "Hannibal" Stel hij had Rome wel vernietigd.

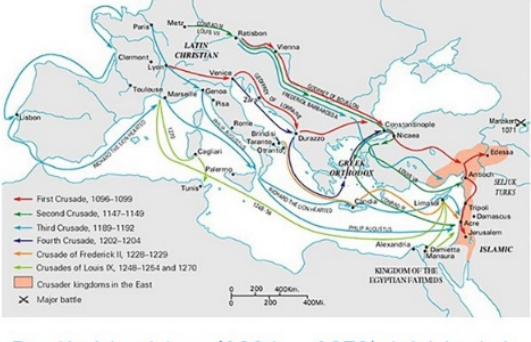

De Kruistochten (1096 - 1270) leidde tot "de nieuwe kennis uit het midden oosten" na de donkere middeleeuwen" occidentalen", kwam ik erachter dat die aan het oostelijk deel van de Bergen woonden; een regio die zich uitstrekt van Le Puy in Frankrijk tot Murcia in het zuiden van Spanje. Afijn, de strategie van de Carthageense generaal "Hannibal" om via het Spaanse schiereiland Rome te belegeren, in plaats via de zee; was een voorloper van de verovering, en massale volksverhuizingen over het gehele Spaanse schiereiland en grote delen van Franrijk. Het terugdringen van de moren vanuit "Parijs", "Reconqiusta" duurde overigens bijna 700 jaar; totdat de 'Spaanse katholieke koningen het "prachtige Al Andalus" vernietigden.

De verhalen over de katharen in en nabije het jaar 1200, een meer vrijzinnig invulling van het toen geldende katholieke geloof is wellicht te begrijpen door nieuwe inzichten en kennis die Europa overspoelden door toedoen van niet 1 maar wel 7 kruistochten. Een bijna 200 jaar durende expeditie die wellicht 1 van de oorzaken is die tot de ontwikkeling van "Noord" Europa hebben geleid. Dit is een aanname, en dient fundamenteel onderzocht te worden. Ook Machiavelli beschreef anno 1500 in zijn "Discorsi" de noodzaak om historische verhalen (die van Titus Livius) op hun "juistheid en precisie" te beoordelen. Niets nieuws onder de Zon! U voelt wellicht al aan dat er gesteld kan worden dat; het begrijpen van complexe uit evenwicht systemen de essentie is van de wetenschap, en dus ook voor historici van essentieel belang. Het goed meten (de integriteit en interpretatie van gegevens) van de historie is essentieel 
"Open Innovatie" - complex \& niet lineair - adaptief (?) en uit evenwicht

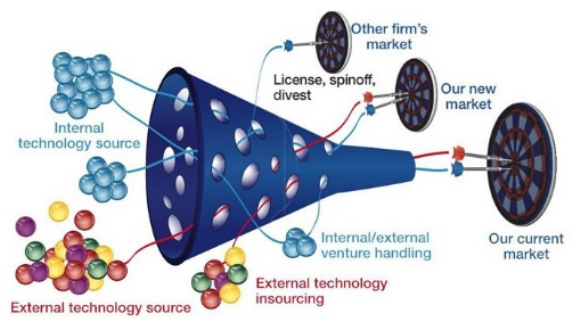

Gebaseerd op ervaringen binnen het VUmc, Pharma Bioresearch, Organon, DSM en de analytische vakgroep aan de VU is het duidelijk dat veel R\&D-organisaties continue aan veranderingen onderhevig zijn. Een organisatie of systeem die continue veranderd en dus uit evenwicht is moet gefundeerd zijn op basis van vertrouwen, inspiratie en samenwerking. Financiën en werkprocessen zijn daaraan ondergeschikt. De gedachte dat alleen maar "gemanaged" als zijnde een project kan worden, moet afgedaan worden als minimalisme. Hiervoor zijn er dan ook leiders nodig die middels verschillende strategieën een weg naar de toekomst voor ogen blijven houden; wetende dat er onverklaarbare effecten en invloeden zullen zijn; en dus met onzekerheden kunnen omgaan. Open innovatie een mooie verzamelnaam van een "nieuwe" benadering waarin de kennis in 1 industriële R\&D organisatie, of een specifieke vakgroep aan een universiteit op zich ontoereikend is, zal nog meer vragen om leiderschap. Het middels Excel format kapot rekenen, en het onvermogen om "innovatiepotentieel" uit te drukken in Euros, van complexe samenwerkingen binnen consortia is een groot gevaar. Evenals diegenen die alleen maar met de woorden IP en "te complex" schermen zullen een nadelig effect hebben op "de oplossing naar de toekomst". De samenleving heeft fundamentele doorbraken nodig, en de academici moeten inzien dat zij zelve maar in zeer beperkte mate "innovatief" zijn. Enige vorm van bescheidenheid is hier wel gepast.

De schematische verbeelding van het "Open Innovatieproces" laat wel de openheid van het proces zien, echter de tunnel suggereert wellicht nog te veel een lineair proces. De werkelijkheid is dat het farmaceutische R\&D niet lineair en tijdsbepaald is. De dynamiek in tijd; sommige processen lopen veel sneller dan de andere (de snelheid bepaalde stap is niet altijd de biologie) is evident. Dit is dus ook analoog aan die vreemde oscillerende uit evenwicht chemische reacties. Het industriële R\&D-proces is niet per definitie niet lineair 
Een moderne kreet is "diversiteit' en de toename van wellicht de Chaos. Ik denk dat het duidelijk is dat dit leidt tot meer chaotische organisaties, die een leider met een visie nodig hebben om de maximale energie eruit te krijgen. "Gelijkgestemde groepen blijven heel efficiënt zaken doen, terwijl een groep met grote kennis en karakter tegenstellingen een veel effectievere oplossing

\section{Het "leiden" van R\&D organisaties}

Diversiteit = meerdere karakters van de "dezelfde soort" die leidt tot maximale effectiviteit (adaptief) van innovatieve organisaties in een continue vit evenwicht.

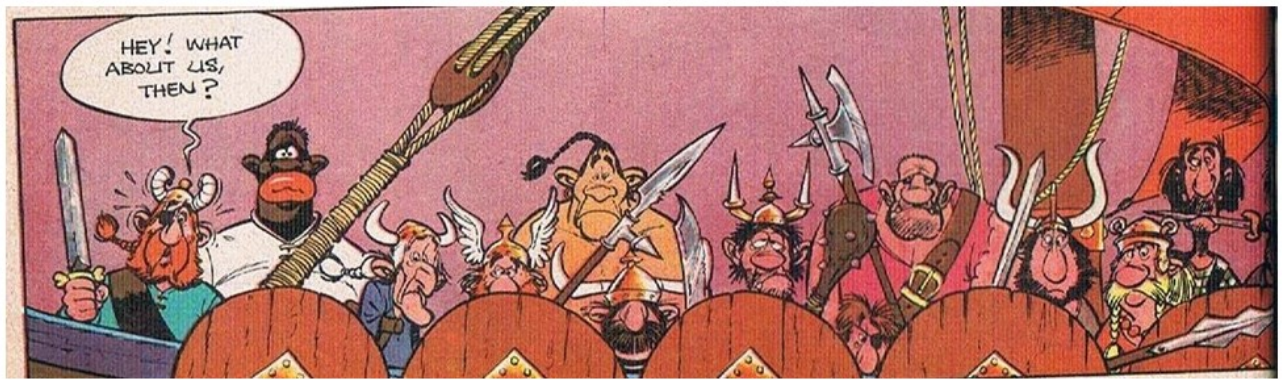

voor een probleem zal vinden"

Wij beginnen aan een reis in de wereld van "onzekerheid" met betrekking tot "veranderende" uit evenwicht systemen.

$\checkmark$ Mijn eerste wellicht iets gewaagde uitspraak heeft te maken met Open Innovatie "Managers laat innovatie over aan leiders die een visie hebben over snelle veranderen systemen, en niet de behoefte hebben om te sturen". Open innovatie (we kunnen het niet alleen), de brug en ook die interdisciplinaire aanpak, zal vragen om leiders die de wil hebben om complexe systemen te willen doorgronden. De wil om op persoons niveau inzicht te hebben over persoonlijke eigenschappen van de collega's en de rol hiervan in de totale R\&D-organisatie kunnen inpassen.

$\checkmark$ De tweede stemming makende bewering heeft te maken met de Wetenschappelijk Scholing (wetenschapper van de toekomst) aan de hogescholen. Deze zal evenals de academische vorming moeten veranderen om aan de "noodzaak van" die breed inzetbare en specialistische onderzoekers te voldoen. Bijvoorbeeld de "Chemicus van de toekomst". En ja de samenwerking met en doorstroming van de hogeschool naar de academie moet veel beter, er zijn zeker diamanten die een niet lineair ontwikkelings- proces hebben doorgemaakt. Maar NEE, als reactie op de recente uitspraken van Anke Mulder als voorzitter van de Saxion Hogeschool; die het promoveren aan de hogeschool propageerde. Promoveren is geen optelsom van publicaties met data, maar mijns inziens een bewijs van in concepten kunnen denken en filosofie. Overigens, HBO-er en MBO-er hebben nemen een belangrijk positie in R\&D-laboratoria in. Zij vormen het cement 
van innovatieve organisaties; iets wat we wellicht in de academie vaak onderschatten.

$\checkmark$ Als derde en laatste de oproep aan alle biologen en alle Omics wetenschappers (volgens mij is het gewoon klinische chemie die ook bij het centraal diagnostisch laboratorium gedaan wordt). Het kan toch niet zo zijn dat de biologie "lineair is" - dus al die publicaties die een "lineaire" correlatie voorstelen moeten van tafel, het gaat om het begrijpen en meten op moleculaire niveau en die informatie in de context van complexe moleculaire systemen te vertalen naar de macroscopische wereld; natuurlijk een enorme uitdaging waar we als wetenschappers voor staan. We zullen in de gezamenlijkheid van specialisten uit verschillende disciplines onderzoek moeten doen en ook de wetenschappers van de toekomst vormen.

Alvorens de inhoud van de leerstoel "Analytics in System Imaging' toe te lichten is het essentieel een korte beschrijving te geven van de analytische chemie en haar rol in de twee laatste "probleemstellingen", de tijd opgeloste stereo chemische uit evenwicht reacties, en het krijgen van een beter begrip van langzaam evoluerende complexe adaptieve materiaal biologie interacties. Vervolgens is het gehalte "organische chemie" in de analyse en Analyse van chemische conversies als integrale wetenschap te benadrukken. Vorige week nog werd nogmaals door collega chemici onderwezen dat er geen echte doorbraken nodig zijn in analytische chemie en zeker niet in Nederland. Het was per slot van rekening toch meer methodologie, of plat gezegd geld vragen voor de aanschaf van een veel te dure grote NMR.

Mijn antwoord is dan ook; de analytische chemie, is 1 van de eerste wetenschappen die de mensheid bezigde en start bij het idee dat het voor een groot gedeelte gaat om het ontwerp, ontwikkelen en toepassen van technieken

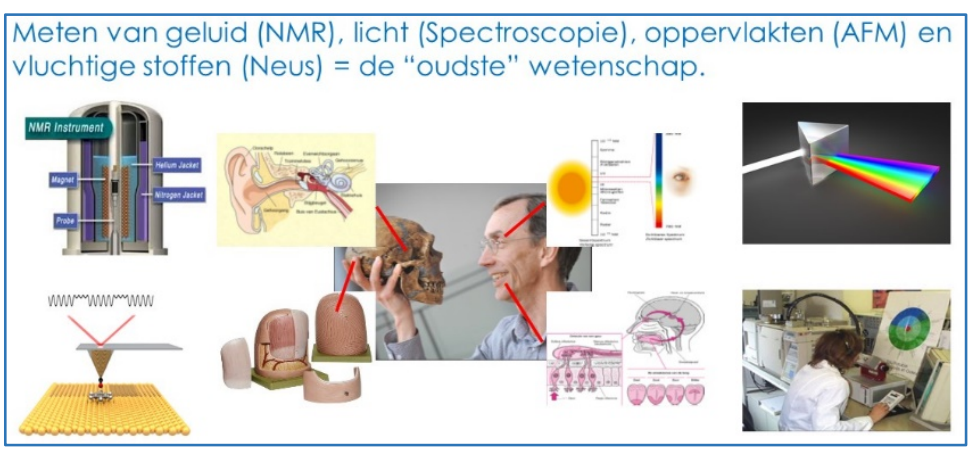
die de beperkingen van de menselijk zintuigen compenseren. In sommige gevallen doen we dat al op bijvoorbeeld vliegvelden met bijvoorbeeld de neus van een hond. Zo kun je je voorstellen dat de NMR een verlengde is van ons oor, de spectroscopie van onze ogen, en atomic force microscopie van onze tastzintuigen. Voor onze neus die veelal gebruik maakt van moleculaire interacties van vluchtige stoffen is nog niet echt een alternatief. Zeker niet als het gaat om de detectie van meerdere stoffen ter gelijke tijd. Daarbij, en wat een zwakte in onze academische vorming was en misschien nog steeds is; is het 
feit dat onze hersenen de informatie van alle zintuigen "simultaan" kan samenbrengen, en via correlatie, noem het wellicht intuïtie, tot belangrijke informatie kan omzetten. Analytici hebben te lang zich gericht op het heel precies en nauwkeuring meten van 1 of enkele datapunten, wij moeten meer integraal naar dynamische systemen kijken en er een tijds opgelost beeld van maken. "Analytics in System Imaging".

Analytische chemie is namelijk het domein van meten en detecteren, waarbij wij fysicochemische eigenschappen van moleculen meten. Deze metingen worden uitgevoerd om de drie basale vragen die zei doorgaans van hun collega's krijgen te beantwoorden. Deze vragen zijn; kun $u$ mij vertellen wat de vorm of morfologie van mijn monster is. Dit kan een vast deeltje die bestaat uit kristallen van 1 soort molecuul, of een zeer complex "apolipoproteine" deeltjes wat opgebouwd is uit vetten, steroïden en eiwitten, zijn. Dit lijkt het domein van de microscopie, maar oude technieken zoals analytische ultracentrifuge zijn nog

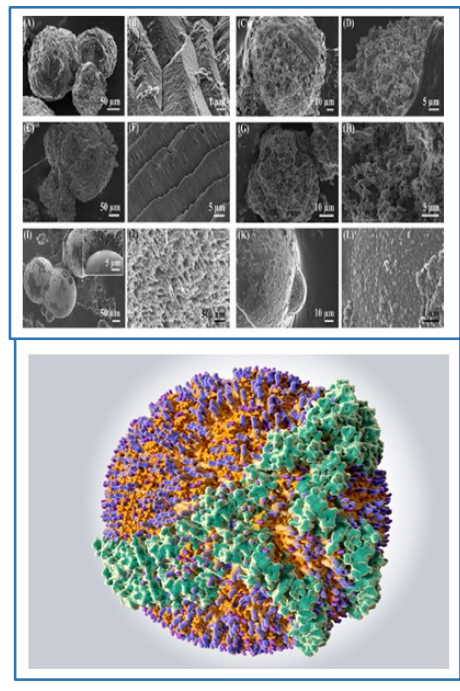
steeds in gebruik. De tweede vraag is, wat is de chemische identiteit van de

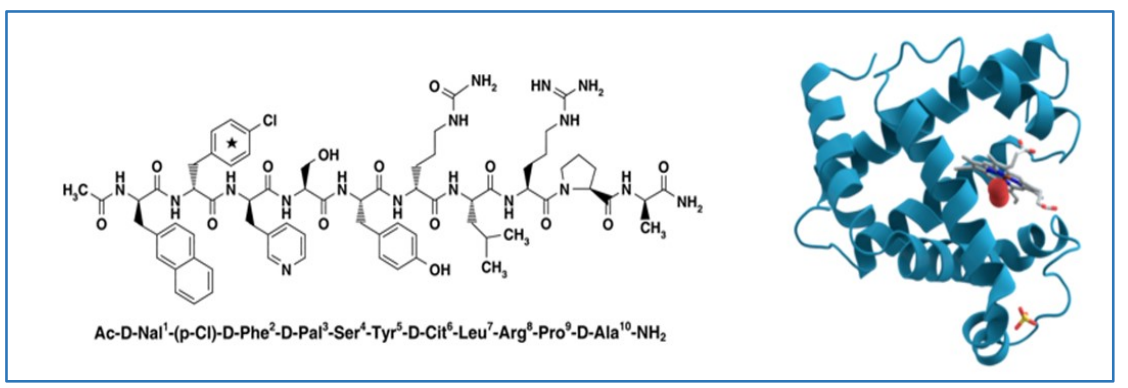
moleculen waaruit mijn monster is opgebouwd. Of wel wat is de 3D structuren van een molecuul. Uiteindelijk zal die bepalen wat de eigenschap van het deeltje zal zijn; hard, zacht, breekbaar of elastisch. Omdat de biochemici steeds gedetailleerder van eiwitten en andere biomoleculen de structuur en activiteit willen kennen om uiteindelijk de biologie van cellen te begrijpen, zijn er natuurlijk die hele dure NMR en massaspectrometers, waarmee ik graag speel, nodig. Toegegeven, het moet gezegd worden dat met een UV-detector van 10 kEuro ook al veel informatie verkregen kan worden. De studenten moeten dit begrip onderwezen worden, en niet alleen leren spelen met grote dure apparaten.

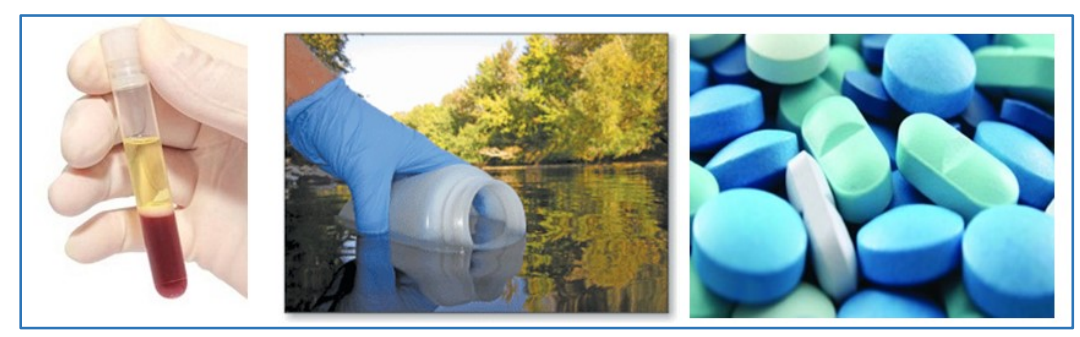

De derde en voor velen wel bekende vraag is "hoeveel" van een soort molecuul er in mijn monster aanwezig is. Dus hoeveel cholesterol 
bevat mijn bloed. Of hoeveel pollen zijn er zodat ik zeker weet dat het vandaag voor mij een "allergie" dag is. We vragen steeds vaker om het inschatten van "risico"; best handig maar op het moment dat het zover is heeft je neus het al door! Je zou je kunnen afvragen of het slikken van anti histamine tabletten de dag voor de waarschuwing wel zo verstandig is.

Uiteindelijk is het, evenals het humane brein, zaak om technologieën te ontwikkelen die simultaan een antwoord geven op deze drie vragen. Het vormen van academische analytici en chemici moet dus ook anders. Het begrip hebben van elektronen dichtheden, de daarbij horende molecuul structuren, om vanuit die kennis biologische of materiaal activiteit te begrijpen, is

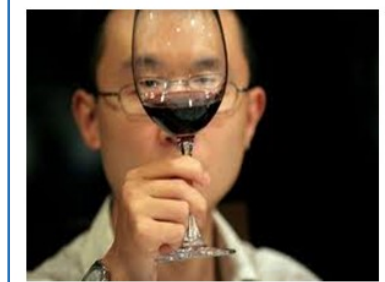

Kleur \& Viscositeit (Ethanol)

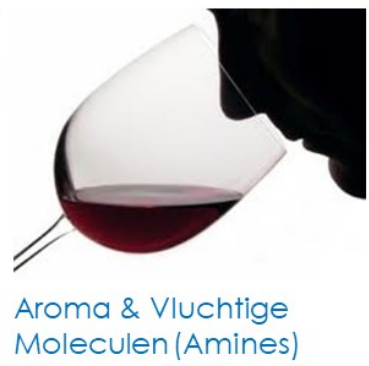

Moleculen (Amines)

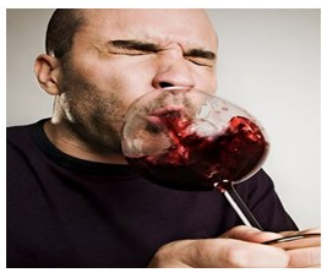

Bittere smaak, (Tannins)

essentieel.

Als voorbeeld, voor meerderen van $u$ hoogst waarschijnlijk voor de hand liggend. Het meten van de

kwaliteit van een wijn is niet triviaal. We kunnen met de ogen, de viscositeit (en dus alcoholgehalte), de oxidatie graad (dus oudheid) bepalen, en concluderen dat het om een oude dame gaat die best pittig is. Door de neus te gebruiken, kan gesteld worden dat het om een fruitige Syrah druif gaat. Maar al die informatie is waardeloos als blijkt dat er toch een raar smaakje aan zit. Een bewijs, om evenals wij mensen dat vaak doen; om integraal en tijds opgelost te meten. Naast de noodzaak om de analyticus van de toekomst anders te vormen voor wat betreft zijn of haar eigen vakgebied; is het van belang de taal van de andere wetenschappers te kunnen begrijpen. Al deze uitdagingen vragen om nieuwe technieken, of met een nieuwe techniek kan beter ingespeeld worden op de toekomstige vragen van collega-wetenschappers.

Een belangrijke
vraag bij de
behandeling van
niet alcoholische
vette lever in welk
stadium deze
ziekte is
aanbeland. Er is
namelijk een punt
van "no return";
en behandeling is dan niet effectief. Mijn collega Ron Heeren heeft met zeer geavanceerde MS 
Imaging technieken, aangetoond hier snel een antwoord op te kunnen geven. Zeer zeker een doorbraak, waar plaats opgelost meten; indicatief is voor de verschillende stadia van ziekten.

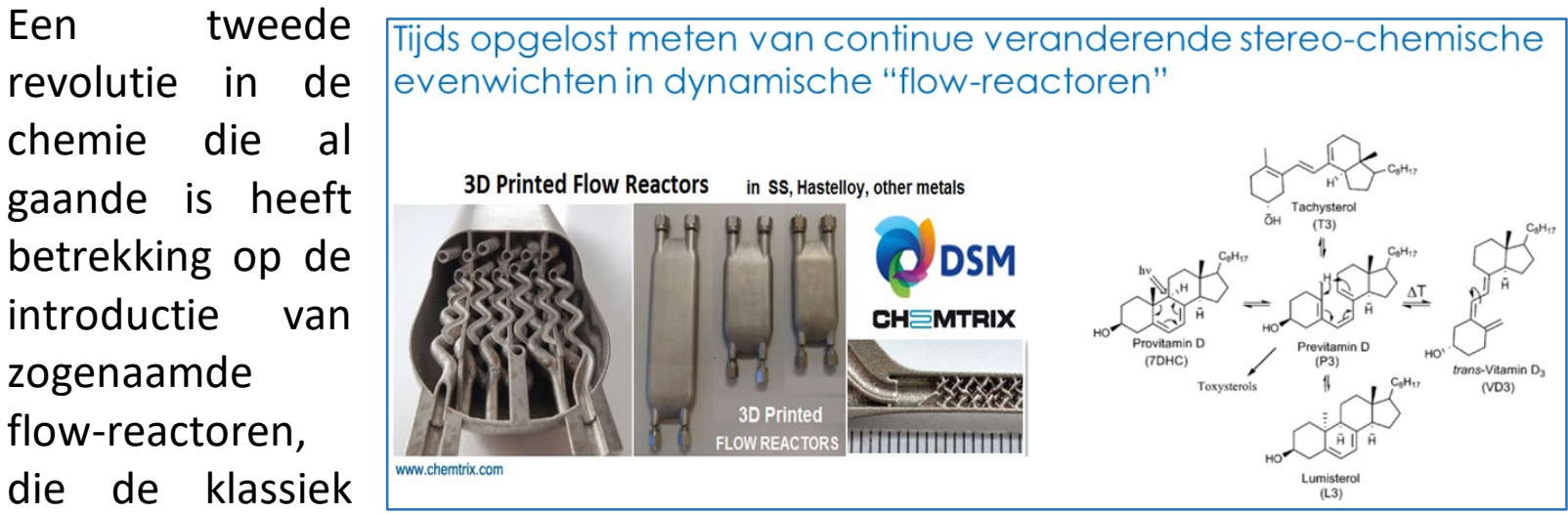

"batch" productie van bijvoorbeeld farmaceutisch actieve stoffen moet vervangen. Deze aanpak leidt tot een vergroening en dus verlaging van het milieueffect doordat minder oplosmiddelen gebruik hoeven te worden, en een reductie aan fossiele brandstoffen. Dit heeft een effect op de zogenaamde CO2 "voetprint". Echter de chemische conversies die plaats vinden zijn anders van aard in vergelijking met de oude benaderingen; en tijdens het ontwerp van die nieuwe processen is het kunnen meten van alle en vooral stereo-chemische samenstelling van belang.

Een derde voorbeeld, waarbij ook tijd een rol speelt, is de interactie tussen biomedische materialen en de humane biologie. Het ontstaan van lokale infectie en ontsteking reacties is een zorg en het mechanisme

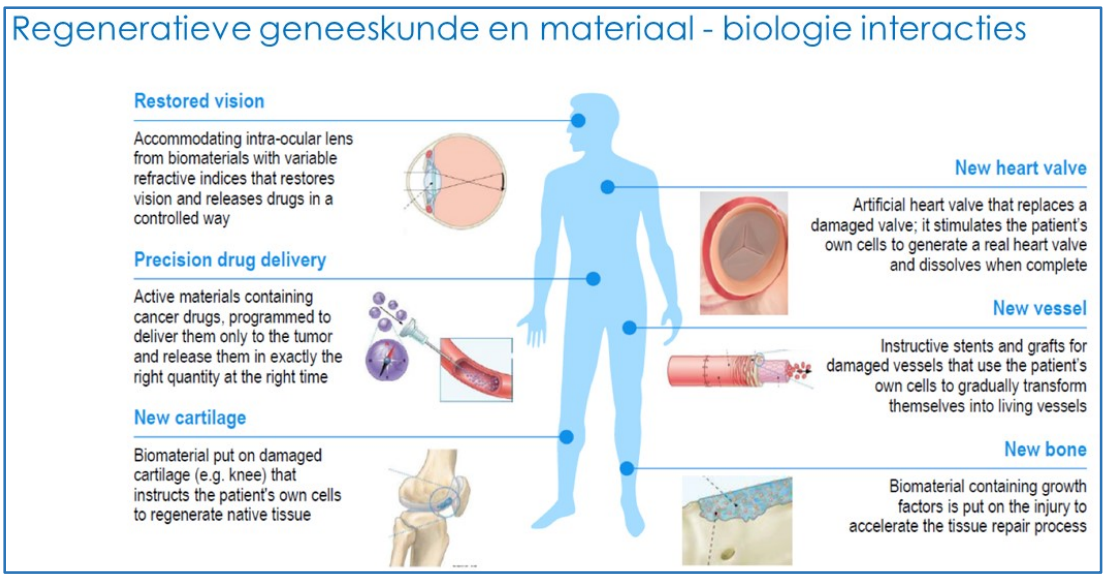
daarvan in nog niet begrepen. Bovendien, is het aantal patiënten wat overlijdt aan op die manier geïnduceerde infecties juist in die landen waar relatief veel antibiotica gebruikt worden een toenemende doodsoorzaak. 


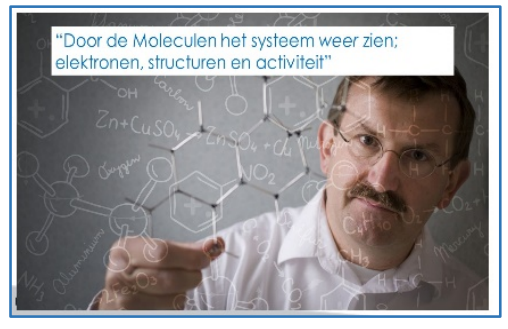

Met de positie van hoogleraar "Analyse" en "tijds opgeloste" moleculaire beeldvorming van "uitevenwicht" systemen", wil ik mij verder verdiepen en mijzelf en mijn studenten onderrichten in adaptieve uitevenwicht systemen.

Dus door de bomen het bos blijven zien, vanuit een gedetailleerd inzicht in de elektronen, moleculaire structuren en hun activiteit.

Ik zal naast de inhoudelijke wetenschap, mij volop blijven inzetten in het bouwen van bruggen tussen wetenschappers van verschillende disciplines, en de mijns inziens broodnodige samenwerkingen van de academie, het $\mathrm{HBO}$ en private partijen. Een vaak onhandelbaar en steeds veranderend proces, waar

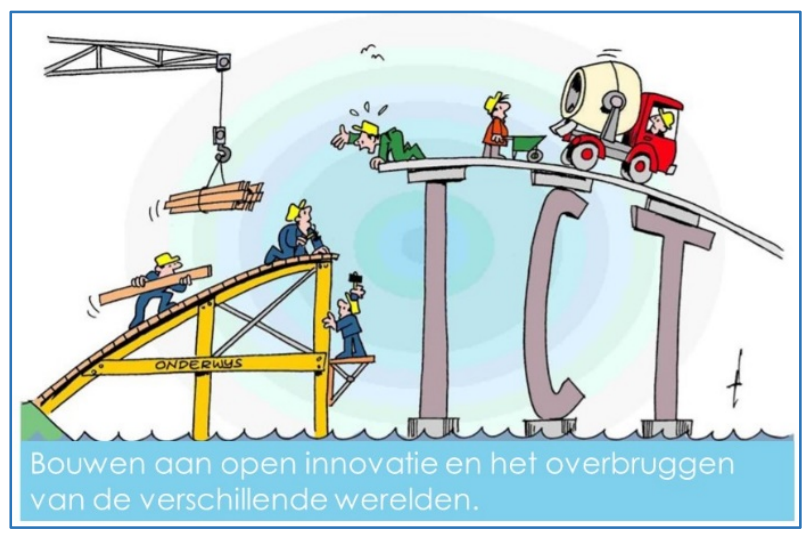
denk ik de lange adem zal winnen.

Naast het onbegrip en de vaak al bekende spraakverwarring over het pakket van eisen voor een dergelijke brug, zijn er soms nog andere schijnbare onoverbrugbare verschillen. Een voorbeeld hiervan is het geloof in de eigen unieke kennis op een specifiek terrein en het overweldigende belang hiervan voor de maatschappij. Dit wordt ook wellicht eens het "Not invented here" syndroom genoemd. Dit geld overigens voor alle partijen, en was bij de grotere industriële R\&D-organisatie geen vreemde houding. Daarnaast is toch het meest belangrijke obstakel financiën en de verschillende financiële systemen. Deze zorgen frequent voor een blokkade om samen te werken; ik zal trachten zoveel mogelijk er omheen te werken; samenwerken is niet iets wat leuk is maar een essentiële voorwaarde om in de toenemende "complexe systemen" die onderzocht moeten worden voortgang te boeken. Vertrouwen in het gezamenlijk meer bereiken is soms nog ver te zoeken. Als we wachten op een wereld waarin deze systemen op elkaar zijn afgestemd, gat er niets gebeuren. Per slot van rekening "Waar een wil is, is een weg". Physici, Chemici, Biomedici en Clinici in 1 team moeten in staat zijn technologische doorbraken te implementeren in bijvoorbeeld de kliniek. Deze redelijk unieke zienswijze en strategie is alom aanwezig binnen de UM, het MUMC en een fantastisch milieu om in te acteren. 
Ik hoor diegenen die zich realist noemen al zeggen; "Honing dat "samen, en in openheid" klinkt en is tot op zekere hoogte toch een naïeve blik op de werkelijkheid. Ik stel hierbij, dat een mate van nederigheid in onze persoonlijke wetenschappelijk kennis is op zijn plaats. Refererend aan de woorden van Emanuel Levinas, en hij stelde "lk word ik in het aangezicht van de ander". Het is mijns inziens dus belangrijk de je eigen acteren tot op zekere hoogte in dienst te stellen van de ander. Daarbij ook op te merken dat het niet belangrijk is kennis "over te brengen", maar de jonge wetenschappers te inspireren en de verwondering van het "normale" over te brengen.
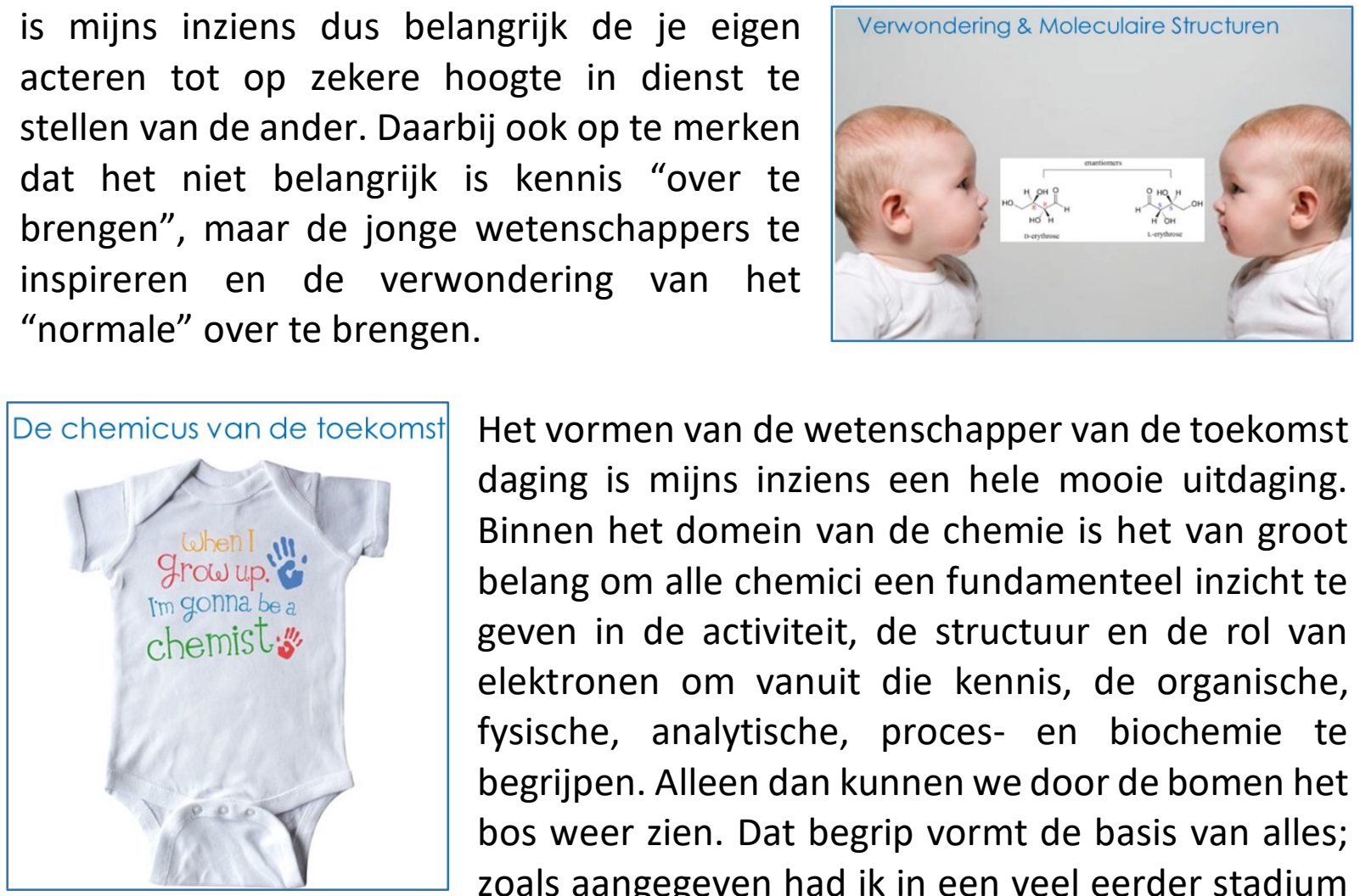

Het vormen van de wetenschapper van de toekomst daging is mijns inziens een hele mooie uitdaging. Binnen het domein van de chemie is het van groot belang om alle chemici een fundamenteel inzicht te geven in de activiteit, de structuur en de rol van elektronen om vanuit die kennis, de organische, fysische, analytische, proces- en biochemie te begrijpen. Alleen dan kunnen we door de bomen het bos weer zien. Dat begrip vormt de basis van alles; zoals aangegeven had ik in een veel eerder stadium de essentie van de citroencyclus beter begrepen als ik het begrip had van deze drie aspecten. Deze basiskennis vormt dan ook meteen de brug tussen alle chemische specialismen. In zijn concept is de vraag van een organisch chemicus hoe hij of zij een koolstof-koolstof binding activeert, hetzelfde als de biochemicus die zich afvraagt waarom een specifiek enzym een stof via een redoxreacties omzet naar een reactief metaboliet. Dit geldt ook voor stroom profielen van vloeistoffen door buizen op het moment dat een procestechnoloog een fabriek ontwerpt of een analyticus met kolom chromatografie werkt. De academische vorming is niet een kwestie van het aan een schakelen van colleges, maar meer middels die colleges en hun samenhang de fundamentele concepten van de chemie te doceren. Naast een fundamentele basis in een wetenschappelijk discipline, zijn andere competenties (de softe) ook van belang. Niet zo zeer om leren aardig te zijn; maar om makkelijk in multidisciplinaire onderzoeksteams samen te werken. Binnen de UM vormt de Problem Based Learning benadering hier perfect invulling aan. $\mathrm{Er}$ is geen toegevoegde waarde van een hoorcollege "hoe ontwikkel ik mijn soft skills", maar juist door tijdens tutorials in teams met voorzitter en secretaris samen te 
werken in het oplossen van "problemen" doen ze ervaring op. In vergelijking tot de "klassikale colleges" zijn de colleges analytische chemie in het derde jaar van de bachelor MSP een verademing. Het is fantastisch te zien dat de meer biochemische opgeleiden, al in dit stadium tijdens de casestudies, de fysisch chemici op sleep touw nemen bij het beantwoorden van de vraag "wat is de link tussen 3D structuur van een eiwit en zijn activiteit". Het inspireren van de "zelf georganiseerde "altijd uit evenwicht" teams is relatief eenvoudig en levert heel veel energie

op.

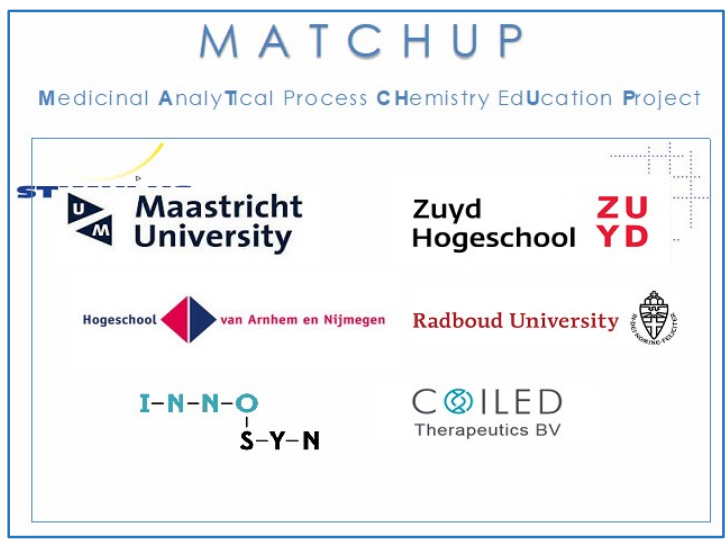

Met de zeer recente toekenning van het MATCHUP-project binnen het Human Capital Programma van het Europese OPZuid programma, kunnen we een Mastertrack binnen de FSE opzetten die invulling geeft aan de "Chemicus van de Toekomst". Naast de UM, de Radboud Universiteit, de hogescholen ZUYD en Arnhem-Nijmegen maken ook de MKB bedrijven COILED Therapeutics en Innosyn deel uit van het project team. Belangrijk is om de chemici van de toekomst uit te dagen om zich te verwonderen over veranderende complexe evenwichten, en bijvoorbeeld het begrip chiraliteit. U kent het wel de discussies over "linksdraaiende Yoghurt". Het doel is, om naast het weer verplichte onderricht in wetenschapsfilosofie met name het basale concept van moleculaire activiteit, chemische structuren en dichtheden van electronen als uitgangspunt te nemen. Hiermee kunnen we invulling te geven aan nieuwe "groene" enzym gekatalyseerde synthese van nieuw stoffen, en het integreren van nieuwe analytische technieken om tijds opgelost naar chemische conversie in flow-reactoren te kijken. De doorstroming van talent uit het HBO naar de academie is ook 1 van de hoofddoelen. De chemicus van de toekomst zal dan ook makkelijker zelf bruggen slaan tussen de biochemici, de materiaal fysici en zelfs de economen als het gaat om de financiering van innovaties in de techniek dan wel samenwerkingen in onderzoek consortia. 
Nadat Robert Voeten, Erik de Lange en Edwin van Leth die al veel voorwerk gedaan hebben, zal het nieuwe team, gebouwd op een grote diversiteit van individuen,

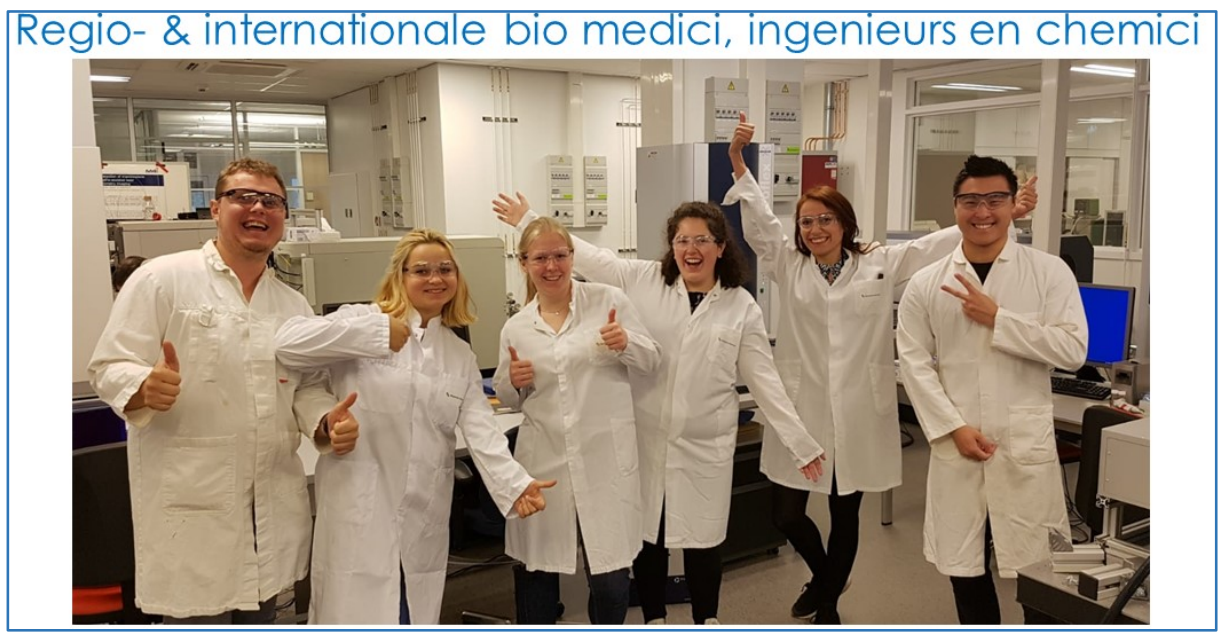
daarbij helpen. Het is fantastisch om op basis van 30 jaar ervaring in het "leiden" van onderzoeksgroepen in de industrie, dit talenten team te vormen door evenals de aandacht aan moleculen om grotere chemische systemen te begrijpen, hier individueel te inspireren en zodoende een onderzoeksteam naar een hoge "zelforganisatie graad" te duwen en de dus capaciteit om met continue veranderingen om te gaan". Ik ben nu al trots op ze!

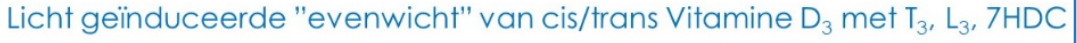

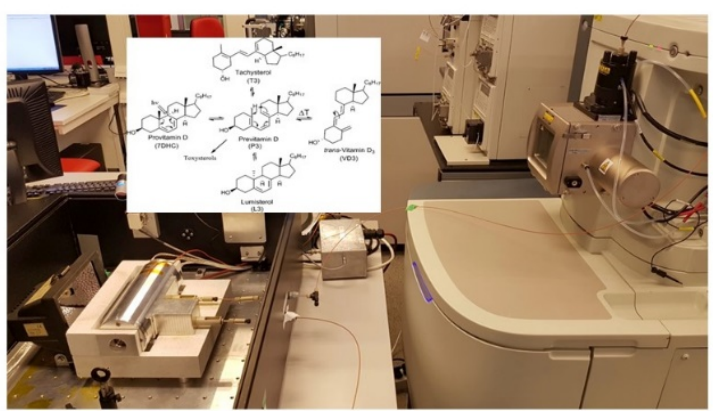

In lijn met het eerder besprokene, zal mijn onderzoek zich richten op de beeldvorming van chemische processen in de milliseconden met een bijzondere aandacht voor activiteit,

structuren en elektronen. Dit omvat universele detectie, micro-flow reactor technieken, ion mobility spectrometry en massaspectrometrie. In nauwe samenwerking met de TU Eindhoven is een begin gemaakt met het koppelen van een flow-reactor waarin via fotonen (licht) de chemische conversie van provitame D naar Vitamine D3 wordt geactiveerd. De kunst is om met lon Mobility al deze zogenaamde constitutionele structuur isomeren van elkaar te scheiden, en dan liefst in het milliseconde tijdsdomein. Eerste resultaten, zijn Detectie van 7HDC (1) en cis/trans (2,3) Vitamine $D_{3}$ - Lamp (L) \& LASER (R)
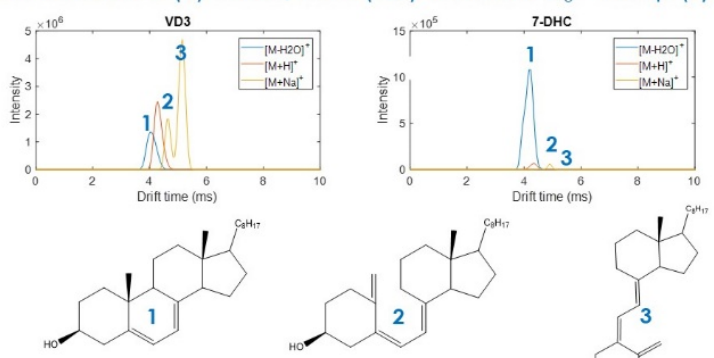
zeer hoopgevend, en sterken mij in het geloof dat analytisch chemici nog meer dan vroeger hun technologieën "integraal" moeten inzetten om alle moleculaire processen op 
verschillende concentratieniveau simultaan te kunnen meten. Een uitdaging waar Nederland in voorop kan en zal lopen. Ik hoop hiermee aan te sluiten bij de noden die mijn collega's voor het voetlicht hebben gebracht.

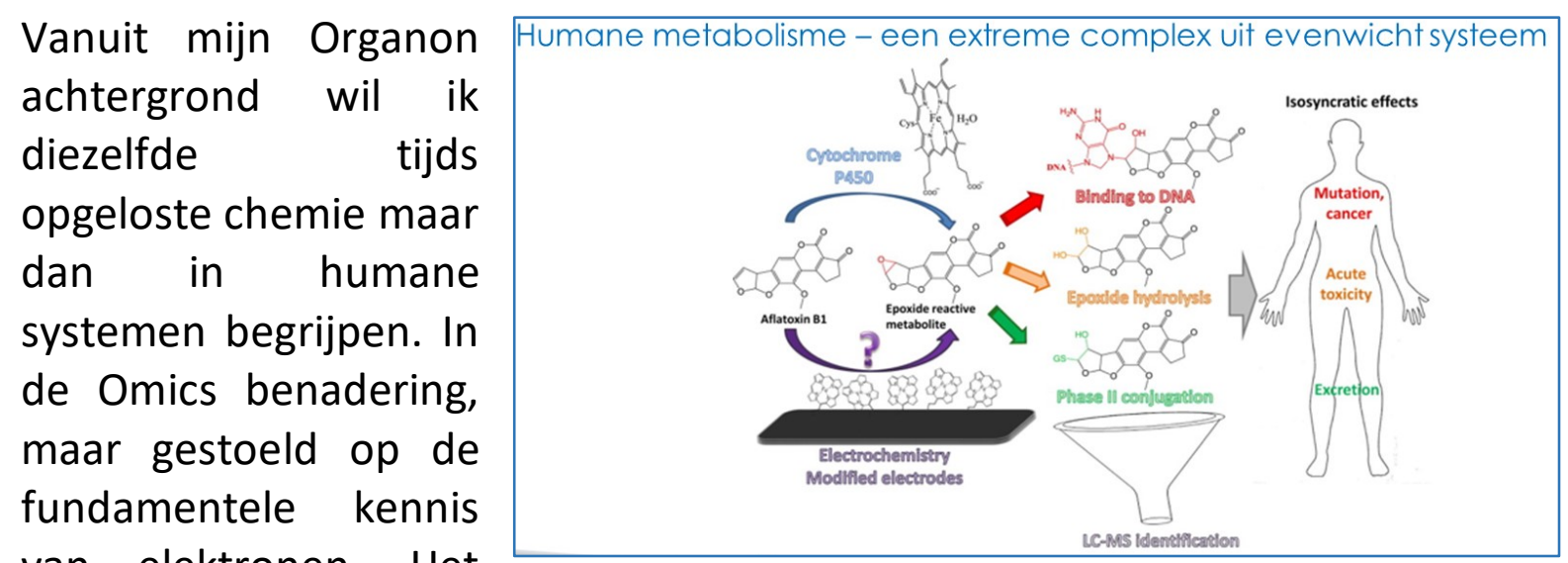
van elektronen. Het

koppelen, zoals Udo

Biochemisch evenwicht in "Orgaan-op-een-Chip" bestuderen

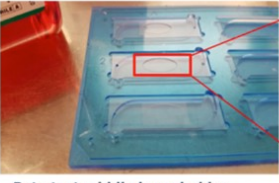

Beta test middle layer holder
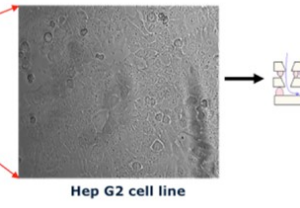

ass

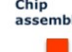

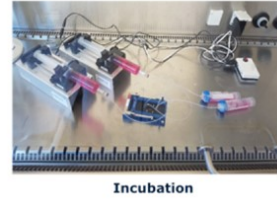

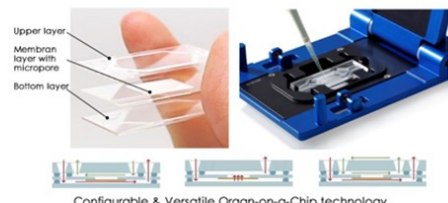

dat ook al deed, van Orgaan op een chip met geavanceerde technieken is een onderzoekslijn, die conceptioneel niet verschilt van de eerste. Het simultaan kunnen

meten van alle moleculen (universeel), zoals suikers, amoinozuren, lipiden, peptiden en eiwitten is de uitdaging. Basaal begrip van micro-fluidica, radicaal chemie liggen voor de hand.

Als laatste, zal ik me richten op het begrijpen van materiaal biologie interacties. Een domein vanuit mijn DSM-tijd. Fascinerende en tegelijkertijd volledig onbegrepen proces. Met de gememoreerde toename van de biomedische materialen; een relevant maatschappelijke onderzoeksgebied. Eerste experimenten met de zogenaamde "Surface Plasmon Resonantie" technologie, laat duidelijk zien dat de adsorptie van verschillende eiwitten aan oppervlakten gerelateerd blijkt te zijn aan de structuur. Afijn, die gebieden waar tijd, elektronen, moleculaire structuren en activiteit een centrale rol spelen.

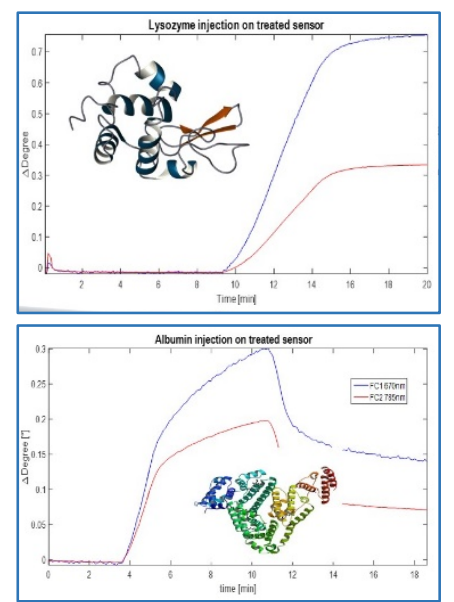


Hierbij ben ik aan het slot van mijn oratie gekomen. Ik heb getracht $u$ een beeld te spiegelen, met betrekking tot de complexiteit van systemen, en dan met name "die evenwichtssystemen die continue uit evenwicht zijn" en bovenal de urgente noodzaak om wetenschappers te vormen die nieuwe inzichten verwerven rondom deze veranderingen. Evenals Nico Nibbering en Ramon Margaleff moet de hoogleraar zelf les blijven geven, en het niet alleen aan de $1^{\text {ste }}$ jaar promovendi overlaten. Evenzo hebben innovatieve R\&D-organisaties geen managers nodig die middels financiële KPI's dan wel rigide HR systemen "sturen", maar leiders die anderen inspireren om het verschil te maken. Verhoog de entropie, en niet zo zeer de enthalpie van organisaties. Hier aan de UM is de overtuiging van "samen zijn we slimmer" in toenemende mate aanwezig. Hierin geldt niet alleen wij binnen de academie maar vooral ook met de industrie. Met mijn collega's binnen de UM, de Radboud, Hogeschool Zuyd, AN en de bedrijven COILED Therapeutics en Innosyn zullen we binnen sponsering van de overheid in het MATCHUP project, ervoor te zorgen dat we "de chemicus van de toekomst" vormen en opleiden. Tot slot, het is mijn missie om de wetenschap inhoud van de analytische chemie te versterken door onderzoek te doen aan dynamische uitevenwicht systemen te doen en hierbij en PhD te vormen.

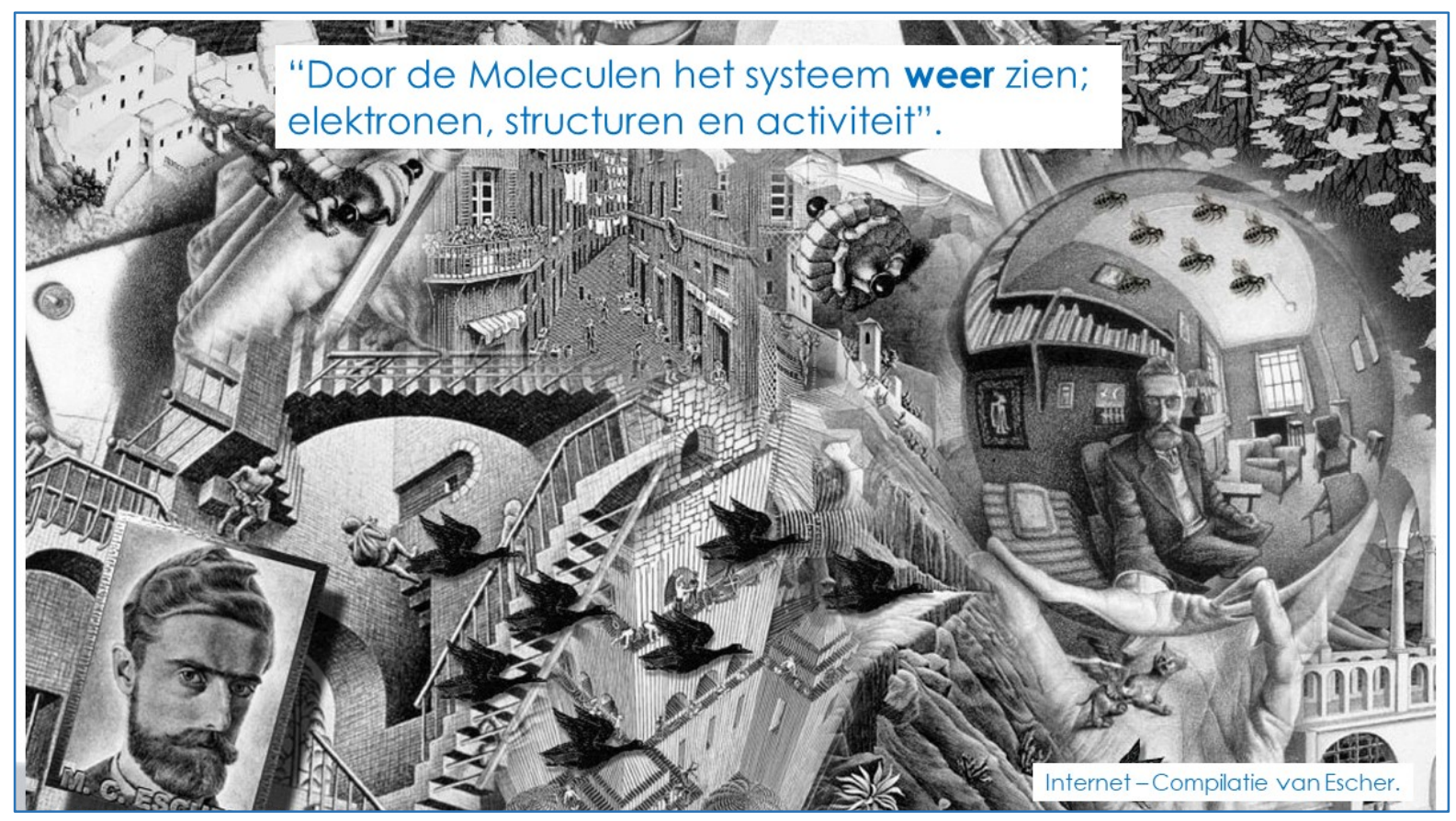

"Ik heb gezegd!" - Prof. Maarten Honing 